University of Nebraska - Lincoln

DigitalCommons@University of Nebraska - Lincoln

Transactions and Reports, Nebraska State

Historical Society

Nebraska State Historical Society

1887

Forty Years Among the Indians and on the Eastern Borders of

Nebraska

Samuel Allis

Follow this and additional works at: https://digitalcommons.unl.edu/nebhisttrans

Part of the History Commons

Allis, Samuel, "Forty Years Among the Indians and on the Eastern Borders of Nebraska" (1887).

Transactions and Reports, Nebraska State Historical Society. 8.

https://digitalcommons.unl.edu/nebhisttrans/8

This Article is brought to you for free and open access by the Nebraska State Historical Society at DigitalCommons@University of Nebraska - Lincoln. It has been accepted for inclusion in Transactions and Reports, Nebraska State Historical Society by an authorized administrator of DigitalCommons@University of Nebraska -

Lincoln. 


\section{FORTY YEARS AMONG THE INDIANS AND ON THE EASTERN BORDERS OF NEBRASKA.}

By Rev. SAMuel Ali.is.

I was born in Conway, Franklin Co., Mass., Sept. 28, 1805. My parents were members of the Congregational church of that place, Rev. John Emerson, pastor.

I was dedicated to God in baptism at the age of five years, and like most in those days, raised to honor my parents. I was catechised by my mother on the Sabbath, and taught to keep it holy. I was raised to industry and good morals, for which I have been ever thankful. My educational advantages were limited, consequently, should this come before the public they will not expect much that will interest them. I shall endeavor to give a short history of what has transpired during my life of seventy years, especially since my stay in the Indian country and on the western frontier.

In my father's family there were eight children, five boys and three girls. I was the sixth of the family. Four of us at this date, 1876, are living. At seventeen years of age I went to live with the Hon. Phineas Bartlet, in Conway Conter, to lcarn the saddle and harness trade. I stayed with him till I was twenty-one, and sat under the preaching of Rev. Edward Hitchcock, afterwards president of Amherst College. After this I resided six months in Williamstown, Mass., where I worked at my trade. I was there under the influence of good socicty and religious privileges. Rev. Dr. Griffin was then president of Williams College. While there I thonght I obtained a hope in Christ. From there I went to Troy, New York, and worked sixteen months with a Quaker friend by the name of Williams. Being among strangers and not having united with the people of God, I got somewhat back into the world, but did not give up fully my hope in Christ. I then went to Ithaca, New York, and commenced work with a Mr. Kirkum, a good old Presbytcrian. I worked for him and others until I left for the west. While in Ithaca I united, for the first, with the Presbyterian church under the charge of Dr. Wm. Wisner, who since died at his son's, at Cedar Rapids, Iowa. 
In the winter of 1834 the church of Ithaca were desirous of raising funds to support a mission among the Indians, and consequently made known their object to the A. B. C. F. M. The board approved and accepted their proposition, and found a Rev. John Dunbar who was willing to go. He came to Ithaca, and with Rev. Samuel Parker and myself as assistants, was fitted out by the church under the patronage of the above named board of missions. We left in the spring of 1834 with instructions to cross the Rocky Mountains, destined to the Flatheads or Nez Perces. We proceeded by steamboat down the Cayuga Lake to the Erie Canal and took a packet boat for Buffalo, then took a steamer on Lake Erie. The wind blowing very hard, the eaptain became alarmed for the safety of the crew and stopped at Salem. We there took stage across Ohio. About three o'clock at night before we reached the Ohio river, it being a dark night and having a drunken driver, the stage upset, cutting a bad wound over my left eyc. I tied my handkerchief over it. We soon grot to a liotel where we changed horses and the driver for a sober one. We proceeded on safely and arrived at Beaver on the Ohio river about sunrise. We breakfasted and took a boat for Cincinnati. Here we stopped the Sabbath, went to church and heard Dr. Lyman Beecher, who was then president of Lane Seminary, Walnut Hill. Harriett Beecher Stowe's husband was a professor.

On Monday, took a boat for St. Louis; when we arrived there we found that the traders for the mountains, whom we intended to accompany, had gone. Ascertaining from the agent for the Pawnees that there was a mission among that tribe, after conferring together and with the Indian agent, we decided that Rev. Parker should return by the way of Mackinaw, see a Mr. Stewart who was agent for the Hudson Bay Company, and get a reinforcement the coming spring in season to cross the mountains. Rev. Dunbar and myself proceeded on to the Pawnees. After conferring with the Pawnee agent we found we could not effect anything until the coming fall, when he would meet us with the Pawnees and make known our business. We proceeded to Fort Leavenworth and summered there, at Liberty, Clay Co., Missouri, and among the missions of the Kickapoos, Shawnees, and Delaware Indians. Their agent was Major Cornings, a good agent, who retained his office under the government some twenty years, and had great influence with the tribes in his agency. The mission breth- 
ren treated us very kindly while we were there. Our time was agreeably spent in learning the Indian character, customs, and manners.

At Liberty we spent some time and enjoyed the hospitality of Col. Doniphan, Mr. Morse, merchant, and Rev. Zantis, a Presbyterian minister. This was the spring after the Mormons were driven out of Jackson county, Missouri. I saw three or four families camped by the side of a large log with loose boards to shelter them from the winter storms, and dependent upon the hospitalities of Clay county people. I was at a meeting in Clay county court house between the Mormons and Jackson county citizens. I heard Joseph Smith make a speech. Col. Doniphan and Rev. Zantis took the part of the Mormons. Probably both parties were to blame, but many of the Jacksonites were desperadoes. I came very near being mobbed mysclf in going from the Shawnee mission to Liberty. If the Mormons had not been so persecuted formerly, probably they would not have become so numerous. Persecution is calculated to build up any religious sect.

We spent some time at Fort Leavenworth. I had a letter of introduction to Major Thompson, from a nephew of Mrs. Thompson of Ithaca. We were kindly received by Major Thompson and other officers of the fort, also Major Morgan, sutler. Major Thompson commanded a regiment of infantry, and was afterwards killed in the Seminole war. He was superseded by Col. Dodge, who commanded a regiment of dragoons, and was appointed provisional governor of Wisconsin, also elected United States senator. His son, A. C. Dodge, was also senator from Iowa, his colleague, Senator Jones, and Hon. Bernhart Henn, representative-the first congressional term of Iowa.

The Kickapoos in those days resided near Fort Leavenworth. The prophet's band had a sort of catholic form of worship. They would meet on the Sabbath for worship, and the prophet would preach in their language. When they broke up, they would form in a line and commence marching in single file three or four times around, saying or singing their prayers, which consisted of characters cut on a paddle, at the same time shaking hands with the audience as they passed by. The characters represented words. As they left they would repeat those prayers till they got to their Father's house or heaven. Their house was marked at the top of the paddle. I had it on paper, but lost it. They had three or four correctors, who carried whittled hickory -ticks about the length of a raw hide. The tribe would meet on Fri- 
days and confess their faults, and receive three or four cuts by those correctors, according to the magnitude of their crime.

There was a French trader by the name of Pensano, who traded with the Kickapoos. His trading house stood where Weston, Missouri, now is. Jos. Rubideau and sons traded with the Iowas, and a small band of the Sacs and Foxes. His post was where St. Joseph now is, it being named after him. In those days there were plenty of deer, wild turkeys, prairie chickens, raccoons, squirrels, and other small game and abundance of bees. White settlers, in the spring of 1834 , just commeneed marking claims at the Nodaway river. At that time there were no settlements above Clay county, Missouri. Some two miles above Rubideau, there were a few houses at a place called Jimtown. All of the country above Clay county has been settled up since.

After spending the summer as I mentioned before, at and near Fort I reavenworth, we proceded up to Bellevue, which was the agency for the Omahas, Otoes, and Pawnees. There we met the agent with the Pawnees in council. When he made known to them our object, they appeared much pleased that we came among them to teach them and their children, and teach them the truth of the Great Spirit, for their minds are dark. After council with them, one of the chiefs of the Loup band wished one of us to go with him to his people, to which we consented. Rev. Dunbar went with the Grand Pawnees, and I with the Loups, or Wolf Pawnees. They are divided into four bands, Grand Pawnees, Pawnce Tappags, Pawnee Republicans, and Pawnee Loups. The latter band speak a different dialect from the others, that is, different pronunciation of words, and different names for some things, but their language is similar. The Arickarees upon the Missouri river, near the Mandans, speak a dialect similar to the Pawnees. The Otocs, Missouries, and Iowas speak the same. The Omahas, Poncas, Kaws, and Osages speak a similar language.

After remaining three or four days at Bellevue, Nebraska, we separated, Rev. Dunbar going with the Grand Pawnees, and I with the Pawnee Loups. These were a delegation of the tribe who came to Beilevue to council with their agent, and receive their annuities. Our first camp was at the Fur Company's fort, about two miles above the present city of Omaha. Major Pitcher, in charge of the post, politely invited me to the fort to partake of his kind hospitalities. I declined the offer, knowing there must be a first time of Indian campunent. 
This was the first time I ever slept on the ground, and the novelty of it prevented sleep, but I had full confidence in my host and red travelling companions, although I knew nothing of their language.

Our second camp was near the Elkhorn river. I was awakened about three o'clock in the morning by the Indians hurrying to saddle up and leave camp, as the prairies were on fire. This was the first sight of the kind I ever witnessed. I could see by their movements that we were in danger. All were hurrying to pack their ponies, and the reader can readily imagine something of the fix I was in, for I had two horses, a saddle and a pack horse. I do not often get excited, but have to acknowledge I was at this time. My host was true to me in assisting me to get away. I was as awkward in packing a horse as a monkey would be running a threshing machine, but I soon learned the art perfectly. The old chief deputized two young Indians to assist me, and even held my stirrups, as if I had been General Sherman, or some other noted general. They have often talked and laughed at my first prairie experience, but I have since, for six months at a time, slept on the ground, without seeing a white man's house. When I was once mounted I had to thank the good Lord for my deliverance. On that same trip, another party camped on the Platte bottoms ; the fire surrounded them, and burned to death four Indians and several horses. I have several times been exposed to prairie fires, and sometimes had to fight to my utmost ability. I could relate many instances of great destruction of life and property among the traders and freighters from this cause.

The third night we camped on the banks of the Platte River. There I learned my first Pawnee word-the name of the moon-and began to become acquainted with the Indians. Mine host, his braves, and deputies took great pains to entertain me. The fourth night we arrived at the village. The chief introduced me to his queens-he had three-also to his children, six in number. As soon as I was seated the old queen placed before me a wooden bowl of buffalo meat and a dish of what the French trader calls bouillon, or the soup that the meat was boiled in, with a buffalo horn spoon. I had scarcely finished my bountiful meal before I had an invitation to dine with one of the members of the cabinet and was escorted to his wigwam with great pomp, my guide having painted his face to cover the dirt and put on his new robe. There I again had introductions to the 
squaws and children. I soon had several invitations from the cabinet officers, and if I could have conversed should have been as proud as any foreign minister. Having been feasted to my heart's content I retired to rest on the best in the lodge, a pair of blankets, a robe, and a deer skin pillow filled with deer hair, which served as pillow and cushion both.

The next day they were busy distributing their goods and getting ready for their winter's hunt. I was sent for to go to the trader's lodge. There I found three Canadian Frenchmen: Laforce Pappan, François Guittar, and a waiter by the name of Piere. They were in the employ of Pierre, Chantean \& Co., of St. Louis, who owned the trading post which I have mentioned on the Missouri River, above Omaha city. I felt somewhat relieved, for although they spoke broken English I could understand them. One of them, F. Guittar, is still living in Council Bluffs. A fter we started on the hunt I was separated from my French friends and did not see them until Christmas. During this time I had no alternative but to learn the Indian language. I went at it in earnest, learning the names of things, and soon got so as to put words together and connect sentences.

Christmas came and I was spared to meet my French friends again. We got up at the chief's lodge, in which Mr. Pappan traded, a dinner of buffalo sausage meat, fried fritters, and coffee. The women of the lodge also added to our sumptuous feast by their cookery. I trust I did not forget the object for which that day should be celebrated. I shall never forget that day, separated from home, Christian friends and associates, but I trust God was with me. I had solemn reflections of the past, present, and future, and pleaded to Him who held even the destinies of the poor heathen, and asked him to enlighten them with that knowledge which will make them the heirs of eternal life.

During the winter my time was engaged in various pursuits, learning the language, hunting buffaloes with the Indians, taking items in cooking, drying meat, dressing robes, and other employments, going to feasts, attending powwow balls, concerts, and medicine feasts, from all of which I could learn something useful. When one is called to feast they consider it is all his or hers they invite one to. In order to please you must take to the lodge in which you live all which you cannot eat, consequently I have carried many buffalo tongues, ribs, 
and other dishes to my boarding house or lodge. They watched, and some young miss or boy would meet me with a smile and receive the bounty, therefore they are glad to have one feasted abroad often. When I went buffalo hunting with the Indians they would give me tongues and ribs as presents, which were always agreeable to my hostess.

They have soldiers for the buffalo hunt, appointed by the chiefs, whose duty is to keep order. "They keep young men and women from the buffalo towards the village, least they frighten the buffalo away. If any is caught in the direction of the buffalo, or go hunting without a general order from the chiefs, he gets a severe flogging. When the order is given for a hunt they prepare and go together, the soldiers taking the lead. When they get near the buffalo they dismount and prepare for the chase. They again mount their ponies, the soldiers still leading till they are discovered by the game, when the soldiers give the word "go," and then everyone for himself. Those who have the fastest horses, and are the most expert with the bow and arrow, kill the most game. They often make a charge on a herd of ten or twelve hundred, killing four or five hundred at one "surround." An Indian knows when he shoots the buffalo in the heart; he often does it at the first shot. He rides after another and so on until the game is scattered beyond reach. They then look up their game. Every Indian knows his own arrows, and seldom has any disputes in this respect. If the Nimrod finds a footman skinning buffalo he looks on like a lord, and gives the poor man half of the meat but reserves the skin. In this way the poor get meat for their families. Some Indians kill as many as three or four at one "surround." When he finishes he puts for home, not waiting for the others. The last ones on the ground are in danger of the enemy, and have been attacked in this way by the Sioux. When they commence a chase there are no wolves in sight, but before they leave the ground the coyotes are running about like dogs for the spoils.

Now comes the cutting and drying the meat, feasting, making medicine feasts, etc. The women cut and prepare the meat, dress the skins, and make moccasins. The men can and do make moccasins while on the war path. The women get most of the wood and water and do most of the drudgery, while the men kill the game and the boys take are of the horses. They often get scoldings or whippings for neglect 
in their duties. There are more broils, jealousy, and family quarrels caused by horses than all other troubles combined. The horse frequently causes separation between man and wife, sometimes for life.

The Indians are great gamblers, especially the men and boys. The women sometimes gamble in small articles when they gct time. The men go it largely, from a horse down to a butcher knife. They have three or four ways of gambling similar to billiards, using the ground for a table. They receive one benefit from it, that is exercise.

They are great for feasting. I have often been called to twenty or thirty feasts in one day, perhaps that is the cause of my being such a great eater. I acquired the habit while with them on their hunts. They eat several times a day when they have plenty, and when they have it not, fast without complaining. The most delicious dish with them is the young taken from the buffalos they kill; the younger the better-the more tender. Besides the buffalo they kill elk, deer, bear, beaver, otter, raccoons, badger, and other small game, and sometimes dogs when they get short of food. I partook of a dog feast once and it would have eaten well if I had not known what it was. In the spring and fall they dig large quantities of wild potatoes that grow in the sand among the willows. These have often kept them from starving. They raise quite a quantity of corn, beans, pumpkins, and squashes.

A long time before the white man brought hoes, axes, knives, etc., among them they used flint rocks for axes, knives, arrow points, etc.; the shoulder blade of the buffalo for hoes; and made stone ware for kettles. Some of the poor old squaws used those pots after I went among them. Some used dogs for hauling their baggage by tying two poles, about eight feet long, at one end over the dog's neck and two cross sticks behind the dog, forming a litter, then place a pack of seventy or one hundred pounds, according to the size of the dog. These animals travel with the caravan of some two thousand souls, besides horses, mules, and jacks. In crossing a stream some of the important Indians would pitch a dog, that happened to be in the way, heels over head, pack and all, which would cause a cry among the canines, answered from all sides by the wolves, and causing many ejaculations from the old women against their lords. At some of their old places that had been deserted I have found relies of pottery, knives, arrow points, and other stone curiosities that were used many years before.

They are very apt in sleight of hand, such as swallowing sticks, 
knives, arrows, etc. They will also let a person shoot a gun at them but are careful to load it themselves.

They have medicine men as doctors, priests, and so on, who practice their deceptions on the majority of their people. These old humbugs rank with chiefs and braves and control most of the tribe as they please. They are initiated into the order while young and trained to practice deception. I do not know that they have a high priest who alone enters the holy of holies once a year; but they have priests who alone handle their sacred oracles, and the common people are not permitted to enter such places while they are in session. They have altars and burn the heart and tongue of some animal in devotion to the Grcat Spirit. Every priest has a sacred bundle made up of a variety of nonsense, consisting of the skins of eagles, hawks, owls, cormorants, woodcocks, and a variety of small birds which are considered as war birds; also skulls of panthers, wild-cats, and other animals; medicine pipes and arrows taken from their enemics in battle, or presents from other tribes in peace partics. Arrows and pipe stems are tied on the outside of the bundle; the small birds are stuffed and enclosed in a buckskin bag with a draw string around the neck, the head sticking out. The arrows have killed some of their enemies and many have been handed down and preserved for generations.

When a party goes to war or on a fricndly visit, before leaving some priest makes a feast and the warrior* attends. 'The priest fills a sacred pipe, consecrates it, and ties a piece of skin over the bowl. The warrior takes it with him for success. If on a friendly visit he presents it and it is accepted and they smoke the pipe together. The peace is good. They exchange pipes and presents, receive goods, horses, ete.

When they go on the war path thcy have two objects in view, to kill, and to steal horses; but they generally prefer stealing without killing, as they do not endanger themselves so much as by killing.

When they go on the calumet dance the Indian adopts a son in the tribe to which he goes, makes a bundle of goods worth from twenty to one hundred dollars, presents them to his adopted son. His son's friends are invited to the bale of goods and each takes a blanket, shroud, or some other article, and gives a horse. In this way one often gets from ten to twenty horses for thirty or forty dollars, worth of goods.

\footnotetext{
* "Partisan" in the cony of original manuscript.
} 
We returned in the spring to their permanent village, not having made a good hunt on account of the Arickarees being in their country, traveling above them, consequently driving off the buffalo. The home of the Arickarees is upon the Missouri river above the Mandans as I mentioned before, and they speak a similar dialect. They came down on a visit. They are bad Indians, and the Pawnees were glad to get rid of them. They are a very superstitious tribe and often cut their arms and breasts as acts of mourning, to appease the Deity. When Gen. Harney made a reconnoissance up the Platte in 1835, the Arickarees got wind of his coming. They were then camped at the forks of the Platte and left the day before the soldiers arrived. The latter found a bundle tied to a pole with an Indian's finger wrapped in it. What their object was no one could tell.

They relate a story of a beautiful young Arickaree girl in their tribe to whom several young Indians made proposals of marriage by offering horses and other presents, all of which she rejected. A.t length one young Indian by improper advances succeeded in seducing her. After an act of mourning she from day to day frequented a certain bluff, a little dog accompanying her. Finally she and the dog became a monument of rock and are there to this day. I leave the reader to believe this or not. I do not, but relate the Indian story as it was told me. Such are their superstitions, which they are full of, but useless to relate.

The condition of the wandering tribe is such there is little hope of benefiting in any way their spiritual condition; but we should not give up the hope, for we are commanded to go into all the world and preach the gospel to every creature.

They are trained to kill and steal from each other, and it is difficult to make permanent peace, when they do, it is only for selfish purposes and they often break the peace no matter how sacred. They have frequent alarms of the approach of their enemies which are often false. They live in constant fear, yet bring much of it on themselves. Most of the tribes kill and plunder for the sake of honor and dissinction; the more scalps an Indian can count the greater the man in cheir estimation. As a mark of distinction, when a man can wear a pole-cat skin on one knee and an otter on the other with hawk bills fastened to the tails of the skins he feels as grand as a lord.

Most of the chiefs inherit their chieftainship, hence they are nu- 
merous, but the majority have little influence. Some of their best chiefs are made so by their agents. They are like the white man, crafty to gain distinction, but are more honest than our politicians, for they do not rob and plunder the government-had rather steal from each other.

They are more hospitable than we are. If a white man goes among them they do not wait for him to beg, but set before him the best they have to eat, sometimes asking for tobaceo, for they know it comes from that source. If we go among them they will divide their last meal without stopping to see if we are going to pay for it.

They returned from their summer hunt the last of September, 1835, with a large quantity of dried buffalo meat; put on the kettles and greased the door posts. Here could be seen feasting in earnest. Their feasts consist of meat, corn, beans, and pumpkins, drumming and pow-wowing, day and night. If a person was not used to their noise he could not sleep. Their corn crop was good, and as they had plenty to eat they enjoyed it hugely.

Their permanent lodges are in shape of a large coal pit except an entrance that projects out some ten feet; five feet wide and the same in height. They build round with two tiers of large forks, the inner forks the higher, with strong poles in the forks; then long poles upon top reaching to the center of the lodge with small willows tied crosswise with bark to the poles; and covered with hay and dirt to the depth of six or eight inches, a round hole cut in the center for the smoke to pass out. But some of their lodges smoke so badly that a person gets a good share of the smoke before it passes out. The fire place is made in the center of the lodge by digging a circular hole in the ground four feet in diameter and six inches deep, with forks for a pole to hang kettles on. Some of their largest lodges are fifty to sixty feet in diameter, the entrance usually facing the east, though in what consists this singular superstition I do not know. The berths or beds are neatly built in a hollow circle at the back of the lodge, two feet high, with willows put upon forks. The partitions between the berths are built light of small willows or flags; the front built in the same manner, with a hole in the center large enough for a man to crawl into. A place is reserved in rear opposite to the entrance. This has no front partition but is left open for their guns, bows and arrows, whips, and for their sacred bundle, buffalo skulls, and other sacred relics. This 
was my berth or bedroom. They often put much before the old skulls and say they eat it when they know that the hungry dogs devour it.

I will now give a description of their skin or travelling lodges. These are built of dressed skins from their summer's hunt that are useless for robes. They take the hair off and dress them soft for lodges, except a few that they leave for parflesh, for meat bales, corn bags, and moccasin soles. Their lodge skins are dressed similar to elk or deer skins, sewed together with sinew in such a shape as to form a hollow circle. The largest contain as many as sixteen to eighteen buffalo skins, and are set up with long, straight, poeled and seasoned poles. When they are on the move these poles are tied three or four together on each side of their ponies, fastened below the packs, and drawn with one end dragging on the ground. The ponies drag these poles, besides carrying two bales of meat, weighing eighty pounds each, or four bushels of corn, and in addition to this, perhaps, two kettles, pans, and other traps, and perhaps a papoose and two or three pups.

Soon after we got to the village, I started with Brother Dunbar and some sixteen Indians for Fort Leavenworth. We went for our mail, and on other business, and the Indians for goods. The first night we camped on the fork of the Big Blue river. Here we found some excellent wild plums. The second day about three P.M., we arrived at the Big Nemaha, where one of the chiefs killed a yearling elk, also found a bee tree-cut the limb off with my hatchet, and got about two gallons of honey. We stopped for the night, of course, and devoured the elk and honey. Here we met with two Frenchmen, and had jolly times, feasting and smoking-in the latter of which I never indulge.

Next morning we started on our journey, and camped on Salt Creek -a little stream near the fort; went into the fort in the morning. We stopped three days, and started back by way of Bellevue; stopped a day or two there, then left for the village, and arrived after fifteen days' absence. We found the women busy harvesting their crops and preparing for the winter hunt.

When they go on their hunt they take several sacks of sweet corn and beans, dry corn for mush, dried pumpkins, dig a quantity of wild potatoes-they grow in abundance up the Platte bottoms-these they boil, peel, and dry, and cook with dried pumpkins.

They made a good hunt in the winter of 1836, killed buffalo, also some elk and deer, at the head of Grand Island. There were plenty 
of large rushes on the island in those days, and the deer were very fat. They also caught plenty of beaver and otter that autumn, it being warm.

They had a skirmish with the Sioux, but had no success from the fact that there was an Indian with the Sioux who was once a Pawnee. He had been killed in battle by their enemies, and left on the battlefield to be devoured by wolves and ravens. The wolves finally gathered his bones together, and restored him to life, when he went among other tribes, on acount of the barbarous treatment of his own pcople in leaving him to be so devoured. And whenever he came to war with the enemy it was useless for the Pawnees to fight, for their guns would flash in the pan, and their bow-strings break. His name was Pahocatawa-I do not know the meaning. He will probably exist as long as there is a Pawnee; they report having seen him several times. They also say that if an Indian or squaw is scalped alive in any tribe, he or she is discarded, and goes to live with a scalped tribe under groundprobably meaning dugouts.

An old Indian told me once he knew one of his tribe to whom appeared a beaver, that wanted him to give the beaver his three sonsfor hehad three - to go and live in the beaver's family ; by doing so he would prosper, and have good success through life. He refused, for he loved his sons much. The animal then asked for two, but still he declined, when the beaver left apparently very much dissatisfied. It bore heavily on his mind for some time after the beaver left, and he began to have bad luck. Finally he could not sleep nights, so heafter consulting the Great Spirit-made up his mind to accept the proposition in part. He was satisfied that the Great Spirit was displeased with his former decision, for he had had bad luck ever sinee the beaver left. The proposition was agreed to by the beaver, and he returned with the messenger, and took one of the sons. The boy lived. several years with the beaver tribe, and finally returned to his father a fine looking fellow-I believe many Indians would improve their appearance in a similar way. I do not know how far that father's faith would compare with Abraham's in offering up his son Isaac, but it would appear from the history to be more selfish. I did not learn, but probably, like Nebuchadnezzar, he ate grass and his finger nails grew like eagle's claws.

I could mention other similar superstitions which appear foolish, and 11 
might not interest the reader. The beaver story reminds me of one thing I have observed. They appear to be divided into clans or families: the Buffalo, Elk, Deer, Wolf, Bear, Beaver, Otter, Eagle, Owl, Hawk, ete. Although they intermarry from one clan to another, still they are tenacious to their own, as it is evident by their names and paintings. One Indian will always paint a bear, another an eagle, etc., on his skin lodge. The clans or families exist, so far as I have learned, among all Indian tribes; some of them consider the wolves so near relatives that they will not kill them. The most of them sometimes appear wolfish, as if they partook of the animal's nature.

Yet, notwithstanding their numerous superstitions, many of them are, in point of intellect, superior to the Negro race. I was United States interpreter some eight years; heard many speches to the government officers from the president down, and know them to be good orators. In tact and good sense some of their specches would not disgrace the halls of congress. They are uneducated, hence their superstitions-unlearned white men are often superstitious, and even learning and better judgment do not always prevent it.

It is generally supposed that there is not much ceremony in their courtships, but it is a mistake. When an Indian sees a squaw he wishes to marry, he goes to the lodge and sits down on the outside. He sits there for some time in a humble attitude, with his head in his blanket or robe, without speaking to anyone; then leaves and repeats his visit the next day; takes the same humble posture for a while, then departs. On the third visit he ventures into the lodge and seats himself at the back of the lodge in the same humble attitude, and leaves without making known his business - but it is nnderstood. On the fourth visit he takes the same position, and if his visits are agreeable the father or guardian invites him to the fire. When some few visible steps are taken for success, he returns and his friends make some presents. He is then invited to the affianced's lodge, and takes her to his; some of his friends give one or more horses according to rank or number of horses. They don't leave to enjoy the honeymoon, but he lives with her in her father's lodge. It is customary for a young man to marry into a family, and if there is more than one daughter he takes the oldest, and so on as fast as they mature, and gives an extra horse for every additional wife. In this way one sometimes gets as many as six or seven wives. They are like the Mor- 
mons in some ways; the oldest wife is Sister Young or Sister Kimbal and so on, and is mistress of the lodge. Each woman, however, has her own bundle of meat, corn, ete., and takes her turn in cooking; and the lord slceps by turns in different parts of the lodge to avoid jealonsy. Some of them have their women in different lodges and own a share in each lodge. In this way they fare better. They have so much system in cooking, dressing robes, corn-fields and other work that they get along better than one would suppose.

My travels with the Indians are now closed. I have been with them two winters and one summer, in all about sixteen months, for the purpose of acquiring their language. I have advanced considerably in the knowledge of the same, learned something of their manners and customs. I have feasted and sometimes fared hard, but have no reason to complain. They have invariably shown me kindness, and $I$ am convinced that when the Indians learn a person and prove him to be their friend, they are kind and generous; but such is the treatment of them by the majority of white men that go among them that they have no confidence in the white man until they prove him. I shall say more on the subject hereafter.

I forgot to mention that a year ago (1835) Rev. Saml. Parker returned with Dr. Mareus Whitman on their way to the Flatheads and Nez Perces, over the Rocky Mountains. They were in company with Mr. Fontenelle, trader at Fort Laramie-or Black Hills. I accompanied them up the Platte as far as Pawnee village. While we were travelling up the Platte valley, near where Fremont now is, Mr. Parker remarked that before forty years church bells would be ringing there-meaning the Platte country. It is not thirty-six years yet, and we have years ago seen what he predicted; and the vast structure of the Union Pacific Railroad completed, and towns and cities have sprung up even on the mountain tops. But to the subject before us.

The missionaries arrived at their destination and established their mission. Brother Parker returned to New York by the Sandwich Islands, and Dr. Whitman returned on horseback in the winter of $1836,{ }^{*}$ and went to Washington to transact some important business connected with what is now Washington Territory, which was likely to fall into the British possessions.

The spring following Dr. W. came back with a reinforcement of

*Written 1856 in the copy, probably by mistake. 
his wife, Rev. H. H. Spalding and wife, and Mr. Gray, for the Oregon mission; and Dr. B. Satterlee and wife, and Miss E. Palmer -now my wife-for the Pawnee mission. I heard of their coming and went to Liberty Landing to meet them. We stopped at Col. Allen's. There Mrs. Satterlee died of consumption. This looked dark for us to part with her before she reached her field of labor, but we tried to become reconciled and feel that it was the hand of God. By request of Dr. S. and her friends we called in the physicians of Liberty, and Dr. Whitman performed the operation of opening and examining her lungs, which proved to be a bad case of consumption. The next day we followed her remains to the grave-the home of all the living. We then returned to our boarding house with sad hearts, with one of our number left behind, or gone before to her eternal rest in heaven. Mrs. Satterlee was from Fairfield, New York. She had a brother, Dr. Wm. Mathew, who was a professor in the Medical College in Fairfield. Dr. S. was from Elmira, New York.

One week after Mrs. Satterlee died we were married by Rev. Spalding-destined to the Oregon mission. When I went down the river from Bellevue to Liberty, I went on the fur company's boat, and engaged a passage for our trip up the river; but when the boat returned there was another captain, who would not stop to take us on board, consequently I had to purchase a wagon and three yoke of oxen, and go up by land. Our Oregon . brethren bought horse teams, and left us at the Big Nemaha. We proceeded up the Platte. When we got there found the June freshet had swollen the river, which was full almost to the banks. We procured a skin canoe of the Otoe Indians, and hired a white man to help us. We had to make several loads, but the doctor and our man were good swimmers. Weswam over half a mile before we could reach the opposite shore. We finally got across, loaded up, and started for Bellevue, which was about fourteen miles distant. After arriving at Bellevue, I procured four acres and a garden spot-this was in June of 1836-and raised a good garden and some corn.

The Pawnees at this time were about to change their location, consequently we could not move out until they had moved to their new home, which was on their reservation where they have since resided until the spring of the present year-1876-when they were moved to the Indian Territory. 
Myself and wife stopped at Bellevue, and Messrs. Dunbar and Saterlee went out to spend the summer with the Indians, on their summer's hunt. They were gone about two months, and returned to us at Bellevue; stayed about two months with us, and went back for their winter's hunt.

I ought here to mention, that Brother Dunbar went east for a wife, and got a small book published in the Pawnee alphabet, and words, and syllables, and returned in the spring, with his wife.

I went to St. Louis in February with P. A. Sarpy, on horseback, and returned in April with Brother Dunbar and wife. Left St. Louis on the sixth of April, 1837. First night stopped at Luten Island, above the mouth of the Missouri river. There came a snow eighteen inches deep-was fourteen days going from St. Lonis to Bellevuegot home and planted some corn-got the varioloid from a Jim Beckwith, who resides with the Blackfeet Indians. This Beckwith was a negro. He gave the small pox to several on the boat, three of whom died on their way up the river. Several of the Indian tribes above caught the small pox. Beckwith and some 20,000 died of it.*

After they had travelled several days on their winter's hunt, Dr. Satterlee left with the Pawnees for Bent and Sauvrois' fort on the Arkansas river. On their way back, when they got below the forks of the Platte, they discovered a smoke near the head of Grand Island. The Indians said it was probably Sioux, and proposed going around by the bluffs. The Platte bottoms were wide there. The doctor told them that they could go around, but he was going straight down the Platte. Above there, however, his horse had died, and he hung his saddle on a tree. When the Indians left him he was afoot. They were then about seventy miles from the Parmee village. The two Indians got to the village, but the doctor never arrived. The smoke mentioned proved to be from the camp of three Indian traders, two men and a boy. The head man's name was Brady, who had some dispute with the other man, who probably killed Brady. The doctor being present, and probably taking Brady's part, was also killed. The man and boy came to the Pawnee village; the man being wounded in the bowels, appcared to be crazy, raised up from his bed in the night, tried to tear open his wound, and to kill the boy. $\mathrm{He}$ left the Pawnees, and was supposed to die from his wounds, or killed

* This estimate is, of cource, an exaggeration; but it has not seemed best to omit the pas. eage. - EDITOR. 
himself. In June, afterwards, some men were coming down the Platte in skin boats, loaded with robes; when landed at Plum Creek, near the head of Grand Island, found the clothes of Dr. Satterlee, his bones, some hair, and his rifle standing by a bush, with the muzzle down, and the powder horn hanging on the gun. Some of his ribs were broken. His silver pencil was found in his pocket, and a paper with some writing. He was brave, and a good shot, and would not stand to be killed without defending himself, and probably shot the crazy man, and died in self-defense. Here we were deprived of another of our associates. 'The doctor's bones were left to bleach on the prairies, and to be destroyed by the wolves. His labors were short, but his heart was in the work.

Mr. Dunbar went to housekeeping in an old trading house at Bellevue, and we still lived, during the summer, with a Frenchman, where we spent the year previous. In the autumn I built a temporary house to live in, until we could move to the Pawnces. August 7, 1837, our first child was born.

Just previous to this Gen. Atchinson moved the Pottawattomies where we now live opposite Bellevue. Dr. Edwin James was their agent. The doctor was the surgeon in Major Long's expedition across the Rocky mountains. There is a peak in the mountains called James' Peak. When I came to this country he was in Delivan's temperance office in Albany, New York. I called to see him for the purpose of getting some information, then expecting to cross the Rocky mountains. He made a good agent, stopped boats as government required, and examined them to see if they had liquor on board. He was so strict a temperance man that the Indian traders used their influence to get him away. The Indian department offered him a situation among the Osages, but he declined it.

Our son died at thirteen months old and was buried at Bellevue, where we then resided. It was a sad bereavement.

When I first arrived at Bellevue Rev. Moses Merril was there as missionary to the Otoes from the Baptist Board of Missions. They soon moved to their location at the Platte river six miles from Bellevue. He died there and was buried near where Smith's saw mill now is, south-west of Council Bluffs.

There was also a Baptist mission established in 1837 or 8-Rev. Samuel Curtis and wife missionaries. They stopped awhile at Belle- 
vue until the agent established a smith's shop among the Omahas; they were then located at Blackbird Hills near where the Omahas now reside.

Mr. Curtis was appointed teacher for the Omahas. His house was built at government expense and cost some twelve or fourteen hundred dollars. He moved up and staid about a year, then moved back to Bellevue; the smith also moved back. The agent sent men to appraise the house, as the mission board was to defray half the expense of brilding it. They took off the doors and windows ard cached them and some Indians burned the house. Here was an expense of some sixteen hundred dollars to the government, and I don't know how much to the mission board, without any benefit to the Indians. He had no influence with them. The board and government withdrew their support, and he was left on his own resonices. He lived about a year in that condition until he cxhausted his means of support; then wishing to return to the States for his wife's sake, the people made up a subseription paper, and I circulated it and raised means, with what little they had, sufficient to take him back.

I don't mention this to speak disrespectfully of missionaries, or the cause in which they are engaged, but to show how likely they are to fail if not competent for their work. Mr. Curtis could preach a good sermon and probably would be useful in the states, where all was pleasant and agreeable, but did not succeed with the Indians.

An Indian missionary needs to be as wise as a serpent and as harmless as a dove. Missionaries have a great many trials, therefore need strong faith in God and His promises. They need to pray much, labor much, and be kind and affectionate to the heathen tribes among whom they dwell in order to gain their affections to win them to Christ, and then they may fail. The influence of Indian traders and sometimes government officials and employés, is bad. This, together with their superstitions and heathenish practices, retard the progress of missionary labor. Christians in gospel lands don't pray enough and give enough to aid missionaries in their arduous work. It is consoling to them to know that many of their brethren meet at the monthly concert of prayer to pray that God will bless those who give their lives and spend most or all of their days in heathen lands away from civilized society and dear friends.

On account of the hostility of the Sioux we stopped with our fami- 
lies at Bellevue until the spring of 1842 , when we moved out on the reservation, where we commenced operations.

There was connected with us one year George B. Gaston and wife. He then became one of the government farmers, of whom there were four, who broke considerable prairie for the Indians. There were also two blacksmiths, with their assistants as strikers. These were in compliance with treaty stipulations.

We were divided into two settlements as soon as we could prepare buildings. Geo. Gaston, that I mentioned as being one of the farmers, after leaving the Pawnee country, moved to Tabor, Fremont Co., Iowa, where he resided until last year, when he departed this life, a consistent, earnest Christian. His family still reside at Tabor. The forepart of January, 1844, I moved my family to the upper station, three miles from Mr. Dunbar. The snow was so decp we had to go up on the ice of the Loup fork of the Platte to the mouth of Willow creek near our residence. We suffered severely that winter, beginning anew and not being very well provided for. It was also hard on the stock. My calves all died and I froze my fingers several times milking. We had a young babe three weeks old, and the house not very warm. March was the most severe of the winter, and I think it was the coldest winter I have experienced in this country. Myself, wife, and three children in one bed, and the last calf at the foot of the bed, and even then it died. The Indians lost most of their horses and several of the Indians froze to death. Many froze their feet and hands, and one Indian boy froze his limbs so badly he walked several years on his knees till he died.

In the spring I commenced in earnest to fence me a garden and little field; broke the ground, finished my house, built stables, sheds and was well provided for the coming fall. The winter of 1845 was warm and mild and we were well secured from the cold, for which we were thankful. Passed the winter comfortably.

The summer of 1845 I built a school-house-did the work myself, at the beginning of which I split my foot from big toe to instep, twothirds through my foot. My wife was there at the time. She did not stop to look at the cut, but ran home one-fourth of a mile and sent a man back with a horse. During this time I hobbled about on my heel and picked up my tools. I then rode home and it just commenced bleeding. There was no one who dared sew it up, and I had 
to do it myself. When I had nearly finished I fainted from pain and loss of blood. It was some time before I could get about to do much. I recollect caning an Indian some three months after for stealing my corn. Some of them are consummate thieves-that is, the women and the lower class of men, for if they were caught at it they were not much disgraced since they had little influence.

The spring preceding* I commenced school and the chiefs would set their old criers-daily journals_to harangue the village, and on came two or three braves leading a band of some hundred and fifty children. Not more than one-third could get into the house. I had a card with large letters on it and would point with a long stick and name the letter and they would repeat it after me. When they had read the braves would turn them out and fill the house with another flock, and so on till they had all finished reading. The braves would then lead them home. Their attendance was very fluctuating, some days if they were not harangued there would be but thirty or forty. They soon, however, got so they could repeat the letters without my telling them. But when winter came or when they went on their hunts they would take their children with them because. they were afraid of the Sioux, consequently the most of what had been learned would be forgotten. Their being molested in this way by their enemies retarded our usefulness, besides our families were in dauger, our women b ing in constant fear when the Pawnees were on their hunts.

The Sioux and Poncas came several times, killed some of our cattle and stole our horses in the absence of the Pawnees. One time my wife was shot at at brother Ranney's out in the yard going from the chicken house toward the house. She heard a noise like the snap of a gun, looked around and saw two Indians standing about four rods from her. One had a gun, the other was fixing the flint. She was so frightend that it appeared to prevent her rumning until they shot at her. She had a child in her arms. There were two balls in the gun, one lodged in a log the other passed throngh the chinking and lodged in the house back of the bed. As she ran past the corner of the house she staggered and they suppose that they had shot her for they went home and reported that they had killed a white woman. She then ran home, but how she got through the fenceshe does not know. She got into the house, fell or sat down on the floor, and said that the Sioux 
shot at her and Mr. Ranncy. I caught my gun and ran up to Mr. Ranney's. The Indians had then got about twenty rods away. I hailed them. They then turned and shot at me. They shot at my dog, and one of the party shot one of our best work oxen and killed him. That night we gathered all the women and children into one house and we men stood guard, but they did not come back to molest us. They frequently eame to our houses when the Pawnees wre absent on their hunts, but generally in small parties. They were sometimes friendly, and sometimes not so much so. They would leave our houses and go to the village and burn some of the lodges; and if in summer time, would ride throngh the corn fields, cut and destroy the corn. They were often lurking about in small partics when the Pawnces were at their village for the purpose of killing some poor squaws who were after wood or in their corn fields. Sometimes would steal a few horses. This is the custom of all tribes with their enemies and the Pawnees are as bad as any other tribe in this respect.

One time the women of one of the Pawnee Loup chiefs were out after wood, and a Sioux Indian lay skulking in the bush watching them like a wild animal for his prey. A Pawnee saw him. He was so intent watching the women he did not sce the Pawnee until he had crept near enough to capture him. He took the fellow to the village and gave him up to the husband of the squaws. This Sioux, they said, had killed two women of the same chief the previous year. The chief said he thought a good deal of his squaws, but would not kill the Indian, and gave him to a chief of another band, who kept hin some time and protected him from the Pawnees until the spring following. The chief had Mr. Sarpy in his lodge trading robes. The traders build a breastwork of lodge skins, some five feet high, at the back of the lodge to trade behind, and to protect their goods. A grand Pawnee brave eame into the lodge with his gun. The Sioux was sitting by the fire when the Pawnee struck him with the butt of his gum on his head. The Sioux, although stunned by the blow, jumped up and made a leap to get in where the trader was, but they jerked him back, and in less than a minute they had him out of the lodge, and all the old squaws that conld get at him were beating him with thic hoes and axes, giving the, war whoop and powwowing over him. Such is the Indian practice-an eye for an eye and a tooth for a tooth, only more so. 
Sometimes the Sioux came in large parties and attacked them in their villages, and have sometimes driven them from their village, killed several, and stole most of their horses and mules, and burned the village. Some three years after we first moved among them, and they had not all moved over from the Platte-the Loup band had moved, and the other three had partly moved, and had built about sixty lodges. They were attacked early in the morning by a large party of Sioux. They fought until about 2 p.x. Some Pawnees came eighteen miles to assist, but few of the Loup band assisted. They staid at home and fortified their village. The Sioux would make a charge from a high bluff one-fourth of a mile from the village, kill some, fire some lodges, steal some horses, and ride back to the partisan on the bluff; at his command would make another charge, and so on until they had killed abont sixty Pawnces, stole several hundred horses, and fired thirty lodges. The Pawnees finally all got into the principal chief's lodge, made port-holes-his horse pen was filled with horses-and there was a desperate battle. Several Sioux were shot, but they would throw their dead and wounded across their horses and carry them off to prevent their being scalped. The Sioux finally found the Pawnee fire too hot for them and retreated back on their trail with their booty.

The Pawnees were so badly frightened they threw their dead into corn caches and heads of ravines, covered them lightly, picked up some of their traps and left some in their lodges, crossed the river and went about three miles that night. It was on the twenty-seventh of June, I think in 1845 . The next day we went to the village; found two dead Pawnees and one Sioux, which we buried; also found a Pawnee lying in the grass near a creek below the village with one leg broken at the knce. We took him home with quite a number of their traps. There were seventeen dead ponies near the principal chief's lodge. The head chiefs of two of the bands and several of the Republican band, La Shappell, the interpreter (Spanish), with several of their braves-in fact their best fighting men-were mostly killed. The women and children were barricaded in the chief's lodge.

They made the attack on Middle Chief, who was head chief of the tribe, early in the morning, about a mile from the village. He was on foot, with a double-barrel gun, but no load in it; he kept retreating and pointing the gun at them. They fired several shots at him, and shot arrows at him, but did not hit him. 
I had Dr. Satterlee's amputating instruments in my house and offered to amputate the Indian's broken limb; he said he would rather die. I told him he would in that situation, and he died in about three days, mortification took place and killed him. One Pawnee brave was killed near where the battle first began. His head and hands were severed from his body, and a rifle, with a dint in the barrel, stuck into his body up to his neck, and he was shot full of arrows; such is the cruelty of Indians. We were where we could see most of the battle, but thought best not to interfere. Sin is the cause of all battles. If all nations, civilized and heathen, were Christians indeed, and would follow the true principles of Christianity, there would be no wars.

We remained at the Pawnces' about four years and four months, and left in August, 1846. While there we labored hard in building houses, making conveniences for our cattle, breaking ground for our fields and gardens-which we were obliged to do as means of subsistence-at the same time trying to teach the Indians, and benefit them as much as we could hoping the way would be opened, that we could be made useful to them, and exert an influence for their spiritual welfare, but our hopes wcre soon blighted by the frequent hostilities of the Sioux, and the neglect of government to give them the protection they had promised, consequently much hard labor and expense were lost.

We were in the country eight years, doing what we could to prepare the way, before we conld move among them with our families. During that time, Brother Dunbar and myself traveled with them some eighteen months, for the purpose of acquiring a knowledge of their language, manners, and customs. The remainder of the time we were with our families at Bellevue, living in suspense, hoping that the way might be opened that we could go among them. During that time we had but little access to them, but more with the Otoes and Omahas, who were living most of that time near Bellevue. I could understand considerable of their languages, especially that of the Otoes, whose language is pretty and easily acquired.

When we finally left the Pawnee country, before leaving we held a council with the government employes, and decided that it was not safe for us to remain there any longer, for by doing so we exposed ourselves and families.

A few days before leaving a party of Sioux came to our house. 
They visited the school-house where $\mathrm{L}$. W. Platt had a boarding school of Pawnee children. They let the Sioux into the yard, previously, however, putting the children into the cellar. One of the Sioux went half of the way up the chamber stairs, and seeing no one came down, and after they had explored as much as they wanted, they went away; when Mrs. Platt ascertained that one of the Indians was asleep on a bed upstairs, but the Sioux did not discover her.

A few days after, the same Sioux returned with a reinforcement We saw them coming, and put our women and children with the school children upstairs in the school-house. We armed ourselves with the determination that we would not let them inside of the yard. They had an American flag, and one of them handed it over to us, and wanted to get inside. He alone got over the fence, and when he was palavering, and saying "very good,"-meaning the flag-some of them managed to take two horses from the stable, which was outside the fence, when a man upstairs, behind the women, cried out "Our horses are gone." The Indian inside the fort, with the flag, was about as badly frightened as Mr. Cline, and in his hurry to leave, leaped the fence, and forgot the flag, which we thought first of retaining, and him with it; but we finally thought, for our own safety, we had better let them go. If we had all been like Cline they would have overpowered us, for they were three to one. They went to the Pawnee village, and set fire to several of the lodges.

At last we decided to cache our things that we could not take with us, and leave. We did so, and left for Bellevue. Mr. Platt had sixteen Indian children which he took there for protection.

About that time the Mormons had arrived from Nauvoo. A Col. Allen had drafted a regiment of Mormon soldiers for the Mexican war of 1846. A Mormon bishop by the name of Miller had started with about forty families for Salt Lake, as the first company across the plains. We accompanied them back to get the remainder of our things, and when we arrived at our houses we had been gone just one month. During that time no Indians had been there to molest. The last day of our trip we went eight miles ahead of Miller's camp. Soon after we arrived, however, two companies of Poncas met, one direct from their village, the other a war party that had been south-about thirty in number. There were only five of us and three from Miller's camp. The Indians did not behave very well. Most of our men lay down 
to sleep, but two of us concluded the safest the best policy, so stood guard. They told me to sleep, they would not harm anything. I told them all right, they could sleep, I was going to stand guard. They laid down and were soon asleep. In the night we started two messengers back to Miller's camp for reinforcements for we did not know what they might do. The men arrived about daylight and came so still they were upon them before they knew it, being asleep. The Indians were so surprised and agitated in their hurry, were plagued to get their traps. But they soon left and went over to Mr. Renney's (the house) that he had occupied. They went upstairs, cut open some sacks containing wheat that we had stored there and let the wheat run down through a loose floor, then took the sacks with them. We did not know it until they had got so far away we could not overtake them. That day Bishop Miller arrived with his company. We sold them the wheat, loaded up, and the next day started for Bellevue. Brigham Young sent word to Miller not to go to Salt Lake. We returned north to Ponca county and wintered there. The spring following Brigham Young with a company of men left for Salt Lake. That was in 1847-the first emigration to Salt Lake.

The Indian agent turned over the boarding school of Indian children to me, and Mr. Platt went to Civil Bend, Fremont Co., Iowa, to live. Mr. Dunbar went to Oregon, Mo., and Mr. Ranney back east and afterwards to the Cherokees, and stayed there until the war broke out in the south. Mr. Dunbar bought a farm near the mouth of the Nodaway river, Mo., taught school some, preached some, and attended his farm. Afterwards sold his farm and moved over to Kansas, where he and his wife died. I am unable to say whether Mr. Ranney and his wife are alive, or I am left alone to tell the story.

I kept the boarding school two years; after that we lived at Bellevue until 1851, when we moved to St. Mary, Mills Co., Iowa, on a farm, and lived there two years. I think I bought where I now live fourteen years ago. The government urged me for about eight years to become United States interpreter. I was United States interpreter for Gen. Danver's treaty with the Pawnees, which, I believe, was in August, 1856. After President Buchanan's inauguration in the autumn, I went to Washington with Major W. W. Dennison and a delegation of sixteen Pawnees to have the treaty ratified. We staycd there all winter waiting for congress to quarrel over the admission of Kan- 
sas as a state. Almost every member of congress had to make a speech on the Kansas question, and kept us there till April. One of the braves died there and was buried in the congressional burying ground under the direction of Hon. Chas. Mix, acting commissioner of Indian affairs, with great pomp and honor to the poor Indian. After the ratification of the treaty we made our way back by way of New York City, where the Indians, by order of the commissioner, received a quantity of presents.

We arrived home safely the last of April, 1857. They then lived on the south side of the Platte river, opposite and below where Fremont now is in Nebraska. They received one payment there and then moved where they now live, on their reservation at Beaver creek, twenty-two miles above Columbus, Nebraska.

Although Indian children make good progress in reading, and especially in writing, it does them but little good, as they leave the school and forget all they have learned, particularly the boys, for it is difficult to keep them in school after they are some sixteen years old. At that age they commence going to war. They establish their character as braves by stealing horses and killing their enemies. The Pawnees generally prefer the horse stealing, as they are fond of plenty of horses for packing and killing buffalo, but they don't often keep them long, for their enemies do as they do-steal them-and they lose many by exposure to cold. They also use them roughly in packing and on the chase.

I believe in the spring of 1851 we moved to St. Marys, Iowa, and lived two and a half years on a farm called the Fielder farm, threefourths of a mile south of where we now live and have lived for twenty years. We lived here in Iowa when I was United States interpreter, consequently I was absent from home considerable of the time among the Indians, where I had a better opportunity to learn their manners and customs than when $I$ lived in their country. When they moved to their present location-in 1859 I belicve-they had a new agent, Hon. J. L. Gillis, from Pennsylvania. I acted as United States interpreter until his time expired, about the time of the civil war. A Major De Pue succeeded Judge Gillis. While there the Pawnees had several attacks from the Sioux. Gen. Sulley, who was in command of Fort Kearney, was stationed at the Pawnees, with a company of infantry, and Lieut. Berry with some twenty dragoons, and 
when there was an alarm of Sioux the Pawnees would run them three or four miles before the dragoons got saddled, but still it gave them courage having the soldiers there. Judge Gillis was upwards of seventy years old, but would buckle on his pistols, mount his horse, and go with the Pawnees in pursuit of their enemies. This he promised for their protection, as he feared not the face of man, especially an Indian. The Sioux came several times while the Pawnees were on their hunts, and two or three times burned some of their lodges and rode through their corn fields to destroy their corn, but we were not strong enough to prevent it.

The Indians are obliged to live compact in villages for mutual protection and to plant their corn in large fields near by, when if they could scatter out and have their family farms they would do much better; but they have these difficulties to encounter, which greatly retard their progress and prosperity. So it is, and I don't see any prospect for the better. Some of the tribes have one difficulty and some another, and all are diminishing fast every year, and will continue to diminish until they are finally extinct, and that will be soon, unless some plan can be devised by our government to urge or force them to form a colony and establish a government similar to our own; and then they would need a different rule from ours, for they are not sufficiently enlightened to send delegates to our congress, unless, from the Cherokees or Choctaws. I have had forty years' experience, more or less, and am ready to admit that their future prospect looks dark. Our government is disposed to be humane with them, but there is a great deal of money and time spent that is useless. I know this, for I have had experience enough to know that many of our Indian agents who go among them are inexperienced-know little or nothing of Indian character, and care less. If they are smart enough to write a good report, and, having a salary of some fifteen hundred dollars, can steal as much more from the government and Indians, and cover their tracks and let other employés do the same, they come through the mill all right. Then people who travel through the Indian country often wrong the Indians and then complain of their depredations. There is surely a cause for bad Indians; they are made so by bad white men. This I know in a great measure to be true. I do not by any means uphold the Indians in wrong doing, at the same time I am bold to say they are treated wrong and often without redress. Many 
white men are ready to trample them under foot without considering the true cause of the Indians' complaints.

Several years since-soon after the first emigration to Denver and California-there was a company of whites traveling up the Platte bottoms between the Elkhorn river and Fremont, Nebraska. They camped on a little creck that empties into the Elkhorin. One of the company thought that he would show his bravery and shot a poor Pawnce squaw. The Indians being camped near caught the fellow and skinned him. I do not know whether dead or alive, and it matters not in my estimation. The creek has since been called Rawhide creek.

Such are the provocations sometimes by inconsiderate white men, who deserve the name of demons instead of men. I go for equity and right-punish the Indians when they deserve it, but give no cause of offense. If they will not explore and improve their country before we takc it from them and drive off their game and destroy their means of subsistence, let us deal fairly with them and remunerate them for that which belongs to them.

* $*$ * * * * * * * *

The American Fur Company had a trading post some eighteen miles above Bellevue and nine above the present eity of Omaha. Major Joshua Pilcher was in command of the post. I found the major one of the most prompt, candid, and reliable gentlemen I have met with in the Indian country. He was well informed on almost any subject, especially respecting Indians, for he had great experience and was free to give any information that was interesting and reliable. During the Black Hawk war the Sacs and Foxes killed their agent, and Major Pilcher was appointed special agent for that tribe. He was afterwards appointed superintendent of Indian affairs, whose headquarters at that time were at St. Louis, and I believe he died there while in that capacity. He once had control of most of the Indian trade from St. Louis to the Pacific ocean. He one winter performed a journey in the Rocky Mountains several hundred miles, some of the way on snow shoes, his provisions and bedding being hauled by dogs. He traveled by land almost as far as any one could toward the Aretic region and related some startling adventures which I regret I did not make note of.

Mr. Cabana, one of the members of the company, succeded Major Pilcher at the fort. He was a very kind and polite gentleman and 
quite an epicure. There was plenty of wild game in those days anc he employed two hunters. His store-room in autumu was filled with venison, geese, swans, ducks, and other small game. He kept a good negro cook, and would visit the cook room several times a day to see that all was going right. Whatever was served on the table was always in the best style, and he was very attentive to his guests at table and elsewhere. He made one sad mistake. Soon after Peter A. Sarpy made his advent into this country he was clerk for Mr. Cabana, and there was a Mr. LaClair who traded with the Poncas. After LaClair had passed Cabana's fort Mr. Cabana hired several Omaha Indian volunteers, headed by P. A. Sarpy, who pursted LaClair and took from him his outfit of goods, which cost Mr Cabana some thousands of dollars to make restitution.

This I believe was Col. P. A. Sarpy's first act of bravery, and caused his promotion from lieutenancy to captain, but at Mr. Cabana's sorrowful expense. By the by, Col. Sarpy earned the title of "colonel" by some distinction, not as a military man, and I should not do him jutsice without giving him a prominent place among the distinguished Indian traders and frontier men of early days. He possessed some excellent qualities and traits of character; although sometimes rongh and uncouth, was a high-toned gentleman, who exerted a great influence among the whites as well as the Indians. He was particularly gencrous to white men of distinction and wealth, also to the Indians when it paid well, but exacted every penny of his hired men and others who earned their living by labor. Still he was generous to the needy. He was active and persevering in his transactions of various kinds of business; employed considerable capital in Indian and other trade; but was often wronged by his clerks, which vexed him as he was very excitable. For a business man with a large capital he was rather a poor financier. Toward the latter part of his life he became addicted to intemperance-a habit of seven-tenths of the Indian traders. During my acquaintance with him of thirty years he was always kind to me and would accommodate me in every way he could. He was all that could be wished for a man of the world, except the habit of intemperance.

He was extremely fond of good, fast horses and always kept a plenty. He was also fond of good dogs and always had a number. $\mathrm{He}$ had a large black greyhound that was his particular favorite, and wel] 
he should be, for Cuff-that was his name-was very fond of his master and watchful of his welfare. He kept him twelve or fourteen years, till at length some Omaha Indians had committed a theft which exasperated the Colonel, and he became so enraged that he set Cuff on the thieves, who pursued them so closely they considered themselves in danger and one of them wheeled round and shot the dog dead. This so greatly enraged the Colonel that he swore vengeance on the whole Omaha tribe. He called a council of the chiefs, to whom he made a touching speech, appealing to them by his former fidelity and friendship, referring to the desperate conduct of their young men in killing his favorite dog, and, it is said, proposed to the chiefs that the young men be banished from the tribe and go to live with the Kickapoos for a certain time as a punishment, to which they assented. For the foregoing I cannot vouch, but I do know that he had the dog laid out in rich style, had a grave dug, and-according to Indian custom in burying their dead-had a wolf's tail tied upon a pole at the grave, and hired an Omaha Indian to go at stated times for several days and cry at the grave as the Indians do for their dead. During the last few years of his life he suffered much; had several severe attacks, and at last died in Plattsmouth, Nebraska. His relatives lived in St. Louis and his remains were taken there for final interment. It was said that he left a property of $\$ 75,000$, most of which was in St. Louis. He had one brother, John B. Sarpy, who died before him and who was a member of the American Fur Company.

When I came to this country in 1834, John B. Sarpy had charge of most of the company's business. The firm consisted of Pierre Chouteau \& Co., namely, Mr. Chouteau, John B. Sarpy, Bernard Pratte, Capt. Sears, Major Sanford, and young Chouteau. Gov. Clark-of Lewis and Clarke notoriety-was then superintendent of Indian affairs with headquarters at St Louis. He was superseded by Major Pilcher as mentioned above, and afterwards by Col. Mitchell. The superintendent's office was removed to St. Joseph and kept by a Dr. Robinson, and then to Omaha, Nebraska, where Col. Taylor was superintendent, and so on to Superintendent Jenny.

The Indian trader I mentioned in connection with Mr. Cabana, ended his existence by shooting himself. He had been intemperate and took a solemn oath that he would not drink any liquor for a certain time, lived that time almost out, and was met by some friends who 
persuaded him to take a drink with them. He did so and afterwards on sober reflection took a pistol and deliberately shot himself.

Lucien Fontenelle, the father of five interesting children by an Omaha woman, was a man of talents and well liked by those who knew him. He had also great influence with the Indians, especially the Omahas. He was a gentleman in his manners and affectionate to his family. He was a successful trader and in company with Major Drips had a trading post at Fort Laramie and in the spring of 1835 built a log house to store their goods, which they took on pack animals to their fort up the Platte. The house in which he died yet stands on the river bank near Bellevue, close by where the cars of the Southwestern railroad run daily. Notwithstanding his excellent qualities and refinement he followed in the wake of most Indian traders and finally died from the effects of intemperance. There are many now living who know the history of his family. He kept his children in school at St. Louis until they had a fair English education. Albert, the second son, partially learned the blacksmith trade with John Snuffin, now living at Glenwood, and was a good smith. Henry, the youngest, learned the wagon maker's trade and was handy with tools. He still lives at the Omaha Reserve and has a family, his wife being a half blood Pawnee. Susan, a fine girl, is now Mrs. Neils. Logan, the oldest, was a remarkable boy and lived to be an Omaha chicf of great influence in his tribe, and also greatly respected by the whites who knew. him. He was killed by the Sioux in a bloody fight in which he fought bravely. Albert was injured by being thrown from a mule which was the probable cause of his death. Tecumseh was killed in a drinking frolic by his brother-in-law, Louis Neil, who was afterwards almost literally cut to pieces by Tecumseh's friends. Our authorities confined Neil in the Omaha jail for sometime until he was pardoned by Tecumseh's friends. The only fault of the boys was they would sometimes get to drinking and disgrace themselves in that way.

A Mr. Brurie was traveling above in the Sioux country some twenty years since, with three other gentlemen, one cold winter day, and rode on ahcad to select a camping place. He rode farther than he needed to for that purpose and the party pursued on and overtook him and found him sitting on his horse frozen to death. There is so little timber and distances between camping places so far in the Indian coun- 
try, a person needs both caution and experience and sometimes perseverance to keep from frcezing. I have often been exposed in this way, and to prairie fires in the fall season.

There are two missionaries now living among the Indians who came to this country soon after I did,-Mr. Ewing among the Iowas, and Mr. Hamilton among the Omahas. They are still laboring for the good of the Indians, I believe with success.

There were some gentlemen among the Indians as traders in this vicinity that $I$ have not mentioned. There was Laforce Pappan, who was in the employ of the fur company. He was on his way to St. Louis in company with Col. Sarpy in 1848 and took the cholera at Nishnabottany and died very suddenly. He had a Pawnee woman and four interesting boys. She is living among the Omahas, has an Omaha husband. Two of the boys are also living.

There was Stephen Decatur, a well informed gentleman, in the employ of Col. Sarpy. He went to the gold mines and I do not know whether he is living. His family are at Decatur City near the Omaha reserve.

Francois Guittar, who was also in the employ of the American Fur Company, is now living in Council Bluffs. He came to this country about the time I did-in 1833 or 1834.

There was also Baptiste Roy, who had a trading house near the mouth of the Papillion, in Sarpy county. The noted steamboat captain, Joseph La Barge, was his clerk.

This reminds me of a noted rascal half-breed Arickaree by name of Antoine Garrow, who was stopping at Roy's trading house. He was at Fontenelle's trading house, and Fontenelle, knowing him to have headed the Arickarees in killing several white men, and being somewhat intoxicated, shot at Garrow in the yard of his fort. 'The ball having passed through Garrow's hat, he (Garrow) said, "What is that for?" Fontenelle replied, "I meant to kill you." Garrow soon left for Roy's fort. Fontenelle got up a party of five or six men and in the evening went down near Roy's fort; sent two men and called Garrow out doors; took him off some eighty rods and shot him. $\mathrm{He}$ was buried beside a large cottonwood tree on the bank of the Missouri river below Bellevue, ncar where Mr. Tzschuck now lives.

Roy traded with the Otoes but also kept a "doggery." Sometimes there would be some twenty Otoes, Roy and his squaw, all drunk, 
pitching and rolling on the bed and floor at the same time, howling like so many demons from the bottomless pit. That is the way some men used to procure the Indian trade.

Major Culbertson was general agent for the American Fur Company. The opposition company was Ellis Harvey, Joe Recotte, and others. The company in those days sent every year a steamboat loaded with goods to Cabana's fort, about ten miles above Omaha City, and return to reload at St. Louis and meet the June rise of the Missouri river; then ascend to the mouth of the Yellowstone river and forts above that.

Before steamboats ascended the Missouri river some forty years ago, they used to cordelle keel boats from St. Louis up the river to the Rocky mountains. Some days they would make ten, fifteen, or twenty miles. They would wade through mud, water, nettles, and brush with a million mosquitoes at their backs, and pull the cordelle all day, and eat boiled corn with a little grease for stpper. If they had coffee they paid extra for it, and if they did not obey the barger or boss they were threatened to be left on the prairies at the mercy of the Indians. 